\title{
Modification of Binuclear Pt-TI Bonded Complexes by Attaching Bipyridine Ligands to the Thallium Site
}

\author{
Guibin Ma*, Mikael Kritikos`, Mikhail Maliarik^ and Julius Glaser* \\ Supporting Information
}

Figure S1. ${ }^{1} \mathrm{H}$ (a) and ${ }^{13} \mathrm{C}$ (b) NMR spectra of a solution containing $\left[\mathrm{Tl}(\mathrm{dmso})_{6}\right]^{3+}$ and bipy in dmso- $\mathrm{d}_{6}\left(\mathrm{C}_{\mathrm{Tl}(\mathrm{III})}=50 \mathrm{mM} ; \mathrm{C}_{\text {bipy }}=9 \mathrm{mM}\right)$, and the assignements of the peaks (for the notation, see Scheme under Table 2). Spin-spin coupling to thallium is indicated.

Figure S2. ${ }^{13} \mathrm{C}$ NMR spectrum of $\left[\mathrm{Tl}(\text { bipy })_{3}\right]\left(\mathrm{ClO}_{4}\right)_{3}(\mathrm{~s})$ in $\mathrm{CD}_{3} \mathrm{CN}(\mathrm{C}=20 \mathrm{mM})$; only signals belonging the the tris-bipy species are marked. Spin-spin coupling to thallium is indicated.

Figure S3. ${ }^{205} \mathrm{Tl} \mathrm{NMR}$ spectra of the complex $\left[(\mathrm{NC}){ }_{4}\left(\mathrm{~N}^{13} \mathrm{C}\right) \mathrm{Pt}-\mathrm{Tl}(\right.$ bipy $\left.)\left({ }^{13} \mathrm{CN}\right)(\mathrm{solv})\right]$ in dmso $(\mathrm{C}=50 \mathrm{mM})$.

Crystallographic data: Listings of all atomic coordinates, temperature factors, bond distances; unit cell and packing diagrams.

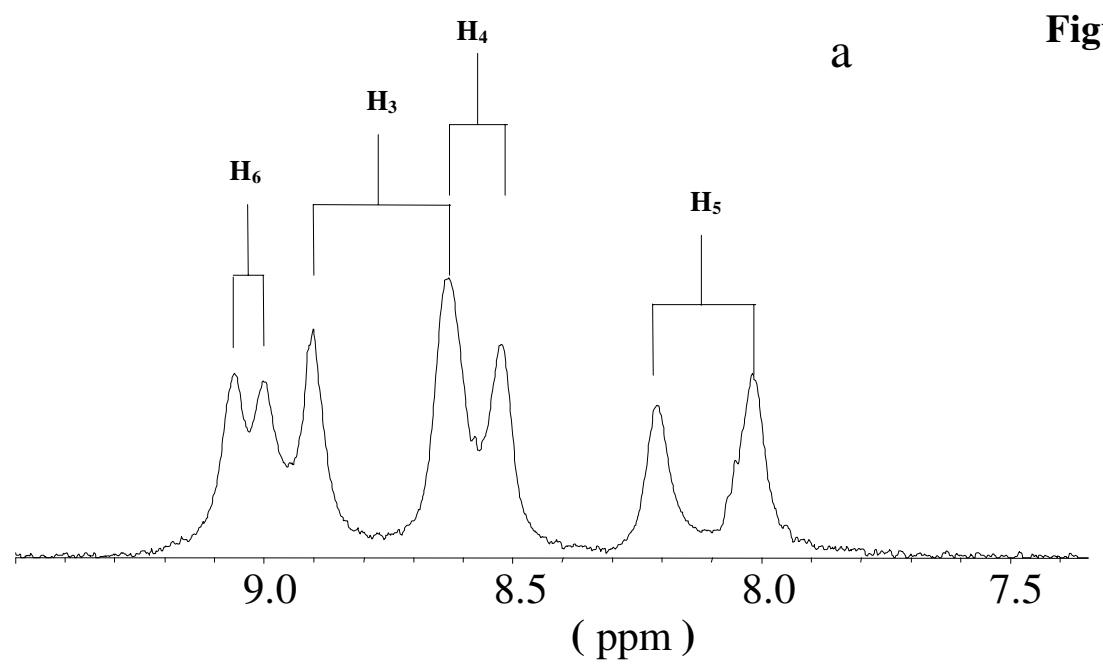

b

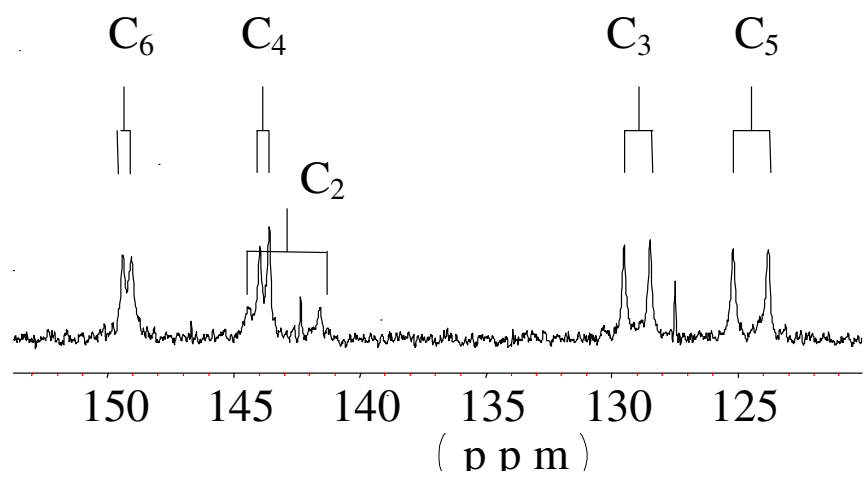


Figure S2

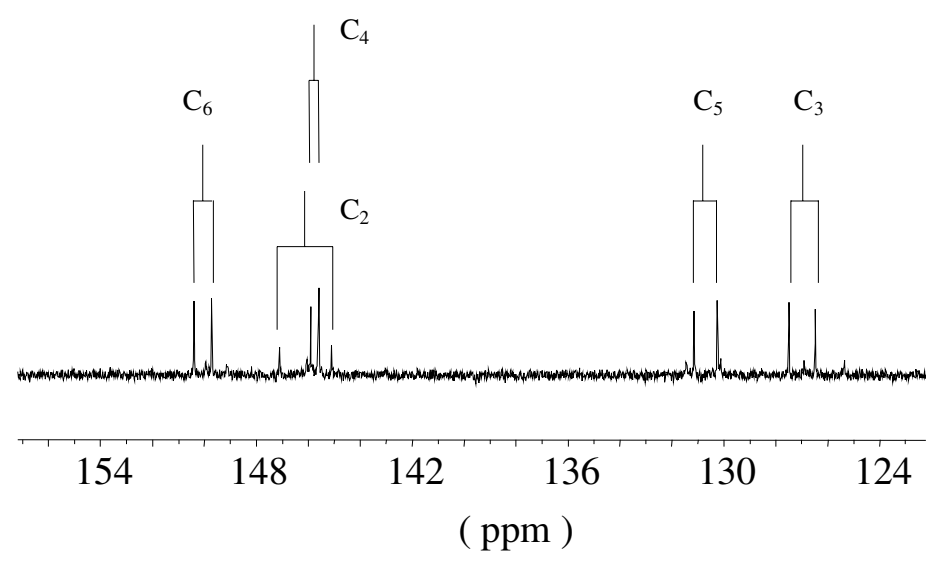


Figure S3

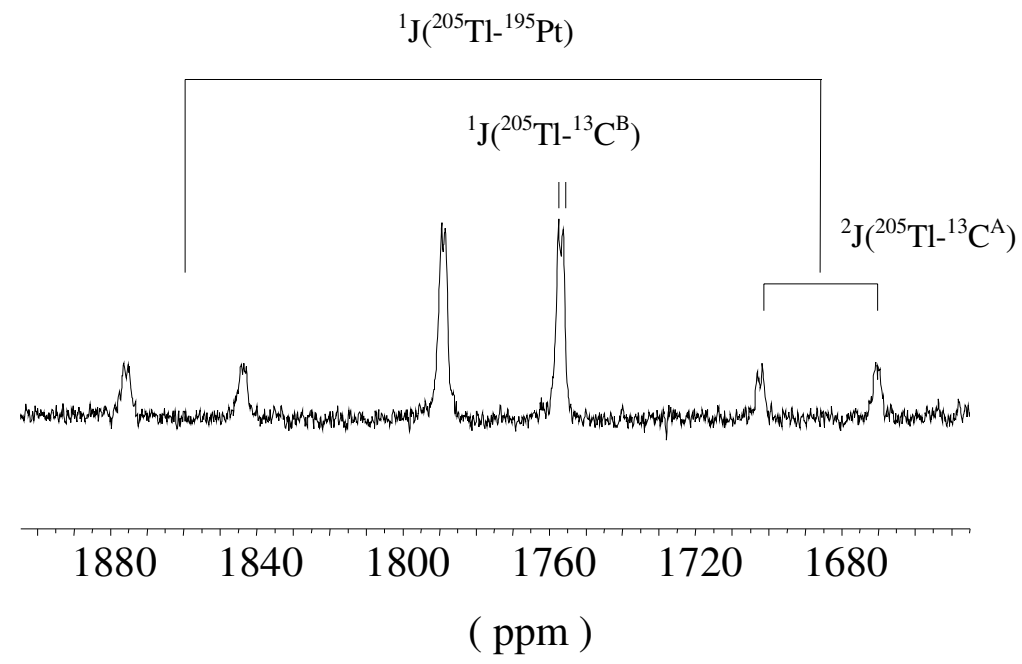




\section{Crystallographic data}

Listings of all atomic coordinates, temperature factors, bond distances; unit cell and packing diagrams.

see cif file 